\title{
Relationship between Organizational Commitment and Organizational Citizenship Behavior (OCB) At Government-Owned Corporation Companies
}

\author{
Muh. Akmal Ibrahim \\ Faculty of Social and Political Hasanuddin University - Indonesia
}

Andi Aslinda (Corresponding Author)

Doctoral students of the Faculty of Social and Political Sciences, University of Hasanuddin

Makassar

Email: agustitantu@yahoo.com

Received: July 15, 2013 Accepted: August 22, 2013 DOI: 10.5296/jpag.v3i3.4379

\begin{abstract}
Organizational citizenship behavior (OCB) is important to solve the complexity of organizational problems in public sector, including BUMN. However, it still has different explanation about factors which have influence to OCB. This study aims to examine the relationship between organizational commitment and OCB at PT Telkom Makassar. Used approach in this research is quantitative by survey methods, through a number of 176 employees from 6 divisions at this BUMN organization by giving response to OCB and their commitment to the organization. Data is collected by questionnaire. Data analysis applies statistical analysis of recursive path model using SPSS version 17.0. Findings of this research reveals that success rate of an organization is also determined by on how organization stimulates their employees upon the organization itself. It can be concluded that organizational commitment positively and significantly relates to OCB at PT Telkom Makassar. Hence, it is suggested that for the forthcoming studies, researcher needs to wield qualitative approach to gather much deeper information in order to explain the phenomenon.
\end{abstract}

Keywords: Organizational commitment; Organizational Citizenship Behavior 


\section{Introduction}

Research on organizational citizenship behavior (OCB) had increased since this concept introduced by Organ in 1977. Nowadays, there is broad consensus that OCB is important to solve the complexity of organizational problems in public sector (Bowler, 2006). OCB grants benefit into public services by re-strengthening bureaucratic values from the good soldier syndrome and strengthening public services ethos (Vigoda-Gadot \& Beeri, 2011). However, a different explanation on a good predictor of OCB still found in some references. Organ (1997) suggests the need of a higher attention on research focus about predictors of OCB based on assumption that employees motivation can offer an empirical explanation about the phenomenon. Niehoff (2000) gives feedback of the concept by declaring that explanation of OCB will be more understood if OCB is seen as a motivational based behavior. Yet, Abuiyada \& Shih (2012) declare that it still some leading theories on motivation have not been investigated its influence on OCB by today.

OCB is discretionary behavior which goes beyond formal task summons (Organ, 1988, 1997). Discretionary means that behavior is not part of role requirements or job description which can be forced, behavior constitutes more on personal choice matters from which its negligence could not be penalized. OCB is multidimensionality behavior which covers altruism, conscientiousness, sportsmanship, courtesy and civic virtue Organ, 1997).

This research investigates the relationship between organizational commitment and OCB. Organizational commitment refers to a psychological condition which is binding individual to organization (Meyer \& Allen, 1991). Although references confess that OCB is motivational based behavior (Organ, 1997; Niehoff, 2000) and that organizational commitment is a good predictor of OCB (Gasic \& Pagon, 2004; Unuvar, 2006; Dickinson, 2009), it still there a few references integrate both factors. References of OCB have not extended a sufficient explanation on organizational commitment effects on OCB (Unuvar, 2006).

Organizational commitment model in this research applies the model of Meyer \& Allen (1991). Organizational commitment model of Meyer \& Allen covers affective commitment, continuance commitment and normative commitment. According to Allen \& Meyer (1991), every employee can experience those three commitment components in different psychological states. Motivation incurs a strong commitment and ultimately encourages involvement in OCB in broadly manner (Chang et al., 2011).

Investigated question in this research is Does organizational commitment positively relates to OCB at PT Telekomunikasi Indonesia Regional Division VII of Makassar Regency? Aims of this research is to analyze: Relationship between organizational commitment and OCB at PT Telekomunikasi Indonesia Regional Division VII of Makassar Regency.

\section{Research Methodology}

This research analyzes the relationship between organizational commitment and OCB at employees' level. This research applies deductive procedure. Applied research strategy is survey. Research population encloses 593 employees of PT Telkom Makassar whom are issued in 18 working units. Six of working unit sample is determined by cluster sampling technique. Then, by the number of 475 employees in 6 working units, researcher took 176 
people as the sample based on the instructions of Barlett, Kotrlik \& Higgins Table (2001). Applied sampling collection procedure is based on opportunity as a result for statistical significance test (Welch \& Comer, 1983).

This theoretical research model includes organizational commitment as independent variable, and OCB as dependent variable. Organizational commitment covers affective commitment, continuance commitment and normative commitment, while OCB is employees contribution in the form of altruism, courtesy, sportsmanship, conscientiousness and civic virtue, which are not claimed to formal reward system.

Data collection instrument is questionnaire. Organizational commitment questionnaire and OCB format employs Likert scale by means of 5 point, starting from strongly disagree (1) to strongly agree (5). All used items to measure variables which are covered in this research model are reliable because obtained Cronbach's alpha is greater than its criteria that is 0.70 as expressly stated by Hair et al. in Gray and Densten (1998).

Examined hypotheses in this research are formulated by:

Organizational commitment relates to employees' OCB at PT Telkom Makassar

$\mathrm{H}_{0} \quad$ There is no relationship between organizational commitment and employees' OCB at PT Telkom Makassar.

$\mathrm{Ha}$ There is relationship between organizational commitment and employees' OCB at PT Telkom Makassar.

Data processing is executed by statistical package for social sciences (SPSS for Windows version 17.0) tools. To check the significance and the strenght of asosiation between independent and dependent variables, researcher applies descriptive statistical test of Kendall's Tau b. Kendall's Tau b (by using the symbol of $\square$ ) measures the strenght of association by cross-tabulation (crosstab). Kendall's Tau is stretched from -1 to $+1(-1 \leq$ $\square \square \leq+1$.)Examined statistical hypotheses as follows:

$\mathrm{H}_{0}:=0$ ( $\mathrm{X}$ and $\mathrm{Y}$ do not have relationship, or, $\mathrm{X}$ and $\mathrm{Y}$ are independent).

$\mathrm{H}_{\mathrm{a}}: \neq 0(\mathrm{X}$ and $\mathrm{Y}$ have relationship, or, $\mathrm{X}$ and $\mathrm{Y}$ are dependent).

The influence of independent variable to dependent variable is interpreted by its relationship. Relationship between examined independent variable and dependent variable shows that the alteration of independent variable is followed in functional manner by the alteration of dependent variable (Welch \& Comer, 1983). 


\section{Findings and Discussion}

\subsection{Organizational Commitment and $O C B$}

Kendall's Tau-b at .380 and Approx. Sig. at .015 show that organizational commitment variable has direct relationship (positive) with OCB variable. Relationships between both variables are significant, while the strength of association is considered as "strong enough".

Table 1 Organizational Commitment * Cross-tabulation OCB

Count

\begin{tabular}{|l|l|l|l|l|}
\hline \multicolumn{2}{|l|}{} & \multicolumn{2}{l|}{ OCB } & \multirow{2}{*}{ Total } \\
\hline \multicolumn{2}{|l|}{} & Low & High & \\
\hline $\begin{array}{l}\text { Organizational } \\
\text { Commitment }\end{array}$ & Weak & 149 & 19 & 168 \\
\hline & Strong & 2 & 6 & 8 \\
\hline Total & & 151 & 25 & 176 \\
\hline
\end{tabular}

Table 2 Symmetric Measures

\begin{tabular}{|l|l|l|l|l|l|}
\hline \multicolumn{2}{|c|}{} & Value & $\begin{array}{l}\text { Asymp. } \\
\text { Std. } \\
\text { Error(a) }\end{array}$ & $\begin{array}{l}\text { Approx. } \\
\text { T(b) }\end{array}$ & Approx. Sig. \\
\hline $\begin{array}{l}\text { Ordinal } \\
\text { by } \\
\text { Ordinal }\end{array}$ & Kendall's tau-b & .380 & .106 & 2,444 & .015 \\
\cline { 2 - 6 } & Kendall's tau-c & .111 & .045 & 2,444 & .015 \\
\cline { 2 - 7 } & Gamma & .918 & .067 & 2,444 & .015 \\
\cline { 2 - 7 } & $\begin{array}{l}\text { Spearman } \\
\text { Correlation }\end{array}$ & .380 & .106 & 5,420 & $.000(\mathrm{c})$ \\
\hline $\begin{array}{l}\text { Interval } \\
\text { by } \\
\text { Interval }\end{array}$ & Pearson's R & .380 & .106 & 5,420 & $.000(\mathrm{c})$ \\
\hline \multirow{2}{*}{ N of Valid Cases } & 176 & & & \\
\hline
\end{tabular}


a Not assuming the null hypothesis.

$\mathrm{b}$ Using the asymptotic standard error assuming the null hypothesis.

c Based on normal approximation.

Theoretically, organizational commitment relates to OCB. Findings of this research reveals that organizational commitment positively and significantly relates to OCB at PT Telkom Makassar. This finding is disclosed by Kendall's Tau-b at .380 and Approx. Sig. at .015. It means that organizational commitment positively and significantly relates to OCB. Relationship between both variables is significant at Alpha 0.05, while the strength of its relationship is strong enough. Research hypothesis declaring that organizational commitment relates to OCB at PT Telkom Makassar is accepted.

Positively and significantly relationship between organizational commitment and OCB is confessed that the alteration in the organizational commitment variable will be followed by the alteration of OCB variable. Increasing of organizational commitment variables will be followed by the increasing of OCB variable. On the contrary, decreasing of organizational commitment variables will be followed by the decreasing of OCB variable.

These findings advocate Beukhof, de Jong \& Nijhof (1998) declaring that success rate of organization is also determined by on how organization stimulates commitment upon the organization itself. By stimulating organizational commitment effectively, employees' psychological bond to the organization becomes stronger and incurs strong encouragement to indicate the more OCB behavior. On the other side, these findings rebut Van Dyne \& Ang (1998) theory declaring that the relationship of organizational commitment to OCB is not significant, and also Shore \& Wayne (1993) theory declaring that organizational commitment relationship to $\mathrm{OCB}$ are negative. These findings show that organizational commitment positively relates to OCB. The phenomenon shows that amelioration of organizational commitment variable will be able to bring positive effect on OCB variable.

The strenght of relationship between organizational commitment and employees' OCB at PT Telkom Makassar have not reached strong level. It relates to the fact that employees' organizational commitment level at PT Telkom Makassar is considered as unfavourable. It has been shown statistically that mean of organizational commitment value for the whole dimension is 3,330 which mean that organizational commitment level of the whole dimension is unfavourable. Employees at PT Telkom Makassar have not completely had organizational commitment including affective commitment, continuance commitment and normative commitment.

Strong enough relationship between organizational commitment and employees' OCB at PT Telkom Makassar means that an effort to fix OCB should consider amelioration of organizational commitment. These days the organizational commitment at PT Telkom Makassar is considered at poor level. The main weakness of organizational commitment variable is on normative commitment dimension. Hence, dominant organizational commitment problems which are faced by PT Telkom Makassar relate to the less of 
commitment to maintain organizational membership and to keep their employees working.

\section{Research Implications}

The findings show that those five discretionary behavior (OCB), i.e. altruism, courtesy, sportsmanship, conscientiousness and civic virtue positively and strongly relates each other. It means that discretionary behavior (OCB) consists of interrelated aspects. For the forthcoming research of Discretionary behavior (OCB), particularly in BUMN organization should begin by the assumption that discretionary behavior (OCB) dimensions do not have differences in term of its antecedents and consequences.

This research is the pilot paper about the relationship between commitment and discretionary behavior (OCB). For the forthcoming studies, researcher needs to wield qualitative approach to gather much deeper information in order to explain the phenomenon.

This research is also being the pioneer of the right statistical test usage about the relationship between organizational commitment and discretionary behavior (OCB). It is found in some references about the implementation of linear regression statistical test, path analysis and structural equation model for the topic, while the questionnaire design is based on Likert scale for ordinal measurement scale. Again, for the forthcoming researches about OCB which is measured at ordinal scale need to apply Kendall's Tau-b statistical test by which it is designed to measure the strength of association through cross-tabulation (crosstab).

Implications of these findings for professional practice is to be used by managers in public organizations as the model which can help them to repair discretionary behavior (OCB) in profit oriented BUMN organizations. Those managers who are eager to raise their employees' discretionary behavior (OCB) should consider some condition to maximize organizational commitment.

\section{Conclusion}

Findings of this research are that organizational commitment positively and significantly relates to OCB at PT Telkom Makassar. Relationship of both variables is strong enough. The phenomenon shows that the alteration at organizational commitment variable is followed in functional manner by the alteration at OCB variable, and that organizational commitment variable and OCB variable is dependent nature.

Organizational commitment at PT Telkom Makassar is still at unfavorable level, and so does the OCB variable. Amelioration in organizational commitment at PT Telkom Makassar will be followed by the increasing of employees' OCB within the organization.

\section{References}

Azeem, Syed Mohammad, 2010. Job Satisfaction and Organizational Commitment among Employees in the Sultanate of Oman. Psychology, 1, 295-299.

Babbie, E. 1990. The Practice of Social Research. Third Edition. California: Wadsworth Publishing Company.

Bartlett, II, James E., Kotrlik, Joe W., and Higgins, Chadwick C., 2001. Organizational Research: Determining Appropriate Sample Size in Survey Research. Information Technology, 
Learning, and Performance Journal, Vol. 19, No. 1, Spring 2001, 43-50.

Bashir, S., and Ramay, M.I., 2008. Determinants of Organizational Commitment A Study of Information Technology Professionals in Pakistan. Institute of Behavioral and Applied Management. Islamabad, Pakistan, pp.226-238.

Bevir, M., 2007. Encyclopedia of Governance. California: Sage Publications, Inc.

Bowler, W. M., 2006. Organizational Goals Versus the Dominant Coalition: A Critical View of the Value of Organizational Citizenship Behavior. Institute of Behavioral and Applied Management.

Chang, Chi-Cheng; Tsai, Meng-Chen; Tsai, Meng-Shan, 2011. The Organizational Citizenship Behaviors and Organizational Commitments of Organizational Members Influences the Effects of Organizational Learning. International Journal of Trade, Economics and Finance, Vol.2, No.1, February, 61-66.

Dickinson, L., 2009. An Examination of the Factors Affecting Organizational Citizenship Behavior. Departmental Honors Thesis, The University of Tennessee at Chattanooga.

Feinstein, A.H., and Vondrasek, D., 2002. A Study of Relationships Between Job Satisfaction And Organizational Commitment Among Restaurant Employees. (Online). Diambil dari andyf@nevada.edu

Gasic, D., and Pagon, M., 2004. Organisational Commitment in the Slovenian Police Force. In Policing in Central and Eastern Europe: Dilemmas of Contemporary Criminal Justice, edited by Gorazd Mesko, Milan Pagon, and Bojan Dobovsek. University of Maribor, Slovenia.

Gibson, James L; John M. Ivancevich; dan James H. Donnelly Jr., 1997. Organisasi: Perilaku, Struktur, Proses., Jilid I. Jakarta: Binarupa Aksara.

Gray, Judy H., and Densten, Iain L., 1998. Integrating Quantitative and Qualitative Analysis Using Latent and Manifest Variables. Quality \& Quantity, Kluwer Academic Publishers, 32: 419-431.

Herzberg, F., 1987. One More Time: How Do You Motivate Employees? Harvard Business Review, Reprint 87507. Sept.-Oct. 1987.

Lok, P., Wang, Paul Z., Westwood, B., and Crawford, J., 2007. Antecedents of Job Satisfaction and Organizational Commitment and the Mediating Role of Organizational Subculture. Working paper, International Graduate School of Business, University of South Australia, diambil dari peter.lok@unisa.edu.au

Meyer, J.P., and Allen, N.J., 1991. A Three-Component Conceptualization of Organizational Commitment. Human Resource Management Review, Volume 1, Number 1, pp. 61-89.

Niehoff, B. P., 2000. A Motive-Based View of Organizational Citizenship Behaviors: Applying an Old Lens to a New Class of Organizational Behaviors. Kansas State University, Department of Management College of Business Administration.

Noor, Ayesha, 2009. Examining Organizational Citizenship Behavior As The Outcome Of 


\section{Macrothink}

Journal of Public Administration and Governance

ISSN 2161-7104

2013, Vol. 3, No. 3

Organizational Commitment: A Study Of Universities Teachers Of Pakistan. Proceedings $2^{\text {nd }}$ $C B R C$, Lahore, Pakistan, November 14.

Organ, D.W., 1997. Organizational Citizenship Behavior: It's Construct Clean-Up Time. Human Performance, 10 (2), pp. 85-97.

Organ, D. W., 1988. Organizational Citizenship Behavior: The Good Soldier Syndrome. Lexington, MA: Lexington Books.

Rifai, H. A., 2005. A Test of The Relationships Among Perceptions of Justice, Job Satisfaction, Affective Commitment and Organisational Citizenship Behaviour. Gadjah Mada International Journal of Business, 7(2), 131-154.

Saville, P., MacIver, R., Kur, R., and Hopton, T., 2008. Personality Questionnaires - Valid Inferences, False Prophecies. Presented at The Psychological Society of South Africa Annual Conference, Johannesburg, August 2008.

Shirley, C., 2010. The Relationships Between Employees' Organisational Commitment, Organisational Citizenship Behaviour And Perceived Job Performance Among Executives: A Case Study of Segi University College. (Online). Diambil dari shirleychan@ segi.edu.my

Spitzmuller, M., Van Dyne,L., and Ilies, R., 2008. Organizational Citizenship Behavior: A Review and Extension of its Nomological Network. In The Sage Handbook Of Organizational Behavior, Barling-Ch06.tex, pp. 106-123.

Ünüvar, T.G., 2006. An Integrative Model of Job Characteristics, Job Satisfaction, Organizational Commitment, and Organizational Citizenship Behavior. Unpublished Dissertation, The Graduate School of Social Sciences of Middle East Technical University.

Vigoda-Gadot, E., and Beeri, I., 2011. Change-Oriented Organizational Citizenship Behavior in Public Administration: The Power of Leadership and the Cost of Organizational Politics. Journal of Public Administration Research and Theory, September 2.

Zellars, Kelly L., Tepper, Bennett J., and Duffy, Michelle K., 2002. Abusive Supervision and Subordinates' Organizational Citizenship Behavior. Journal of Applied Psychology, Vol. 87, No. 6, 1068-1076. 